\title{
Modified Red Muds and Slag Based Hydraulic Binders for Zn Removal: A Matrix-Spiking Approach Applied on Clayey Sediments
}

\author{
Adoum Mahamat Ahmat ${ }^{1, *(D)}$, Walid Maherzi ${ }^{1}\left(\mathbb{D}\right.$, Claude Le Milbeau $^{2}\left(\mathbb{D}\right.$, Mahfoud Benzerzour $^{1}$ and $^{-}$ \\ Nor-Edine Abriak ${ }^{1}$
}

check for updates

Citation: Mahamat Ahmat, A.;

Maherzi, W.; Le Milbeau, C.;

Benzerzour, M.; Abriak, N.-E Modified Red Muds and Slag Based Hydraulic Binders for Zn Removal: A Matrix-Spiking Approach Applied on Clayey Sediments. Minerals 2021, 11, 1189. https://doi.org/10.3390/ $\min 11111189$

Academic Editors: Carlos

Hoffmann Sampaio, Weslei

Monteiro Ambros and Bogdan

Grigore Cazacliu

Received: 3 September 2021

Accepted: 20 October 2021

Published: 27 October 2021

Publisher's Note: MDPI stays neutral with regard to jurisdictional claims in published maps and institutional affiliations.

Copyright: (c) 2021 by the authors. Licensee MDPI, Basel, Switzerland. This article is an open access article distributed under the terms and conditions of the Creative Commons Attribution (CC BY) license (https:// creativecommons.org/licenses/by/ $4.0 /)$.
1 Laboratoire de Génie Civil et Géo-Environnement (LGCgE), IMT-Lille-Douai, 59500 Douai, France; walid.maherzi@imt-lille-douai.fr (W.M.); mahfoud.benzerzour@imt-lille-douai.fr (M.B.); nor-edine.abriak@imt-lille-douai.fr (N.-E.A.)

2 Institut des Sciences de la Terre d'Orléans (ISTO), UMR 7327, Université d'Orléans, CNRS, BRGM, 45071 Orléans, France; claude.le-milbeau@univ-orleans.fr

* Correspondence: mahamat-ahmat.adoum@imt-lille-douai.fr
Abstract: Dredging sediments can be implemented as primary resources in several civil engineering applications, on the condition that the release of anthropogenic compounds meets environmental requirements. The remediation of sedimentary wastes constitutes therefore, a key step before valorization consideration in circular economy schemes. This study focused on $\mathrm{Zn}$ removal from clayey river sediments dredged in northern France (Lille, Saint-Omer and Aire-Sur-La Lys) using a Thermo-Evolved Red Mud (TERM) and a Slag Based Hydraulic Binder (SBHB). The first step consisted in investigating Zn-trapping mechanisms prior to TERM and SBHB application as Znstabilizers. Results underlined poorer metal retention within the most organic sediment (high fatty acids and polycyclic aromatic molecules concentrations), emphasizing the minor role of the organic fraction typology during Zn-trapping. The pollutant displayed its best binding yields within the sediment with the highest interstitial $\mathrm{pH}$ and specific areas, which stressed out the preponderant influence of alkalinization ability and particles size distribution. In a second step, the spiked sediments were treated with TERM and SBHB, which resulted in a substantial lowering of $\mathrm{Zn}$ release at $12 \%$ of stabilizer/sediment ratio. Even though the organic content role was not preeminent during the pollutant trapping, it appeared here influential as delays in removal efficiencies were observed for the most endowed sediment. Two preferential geochemical pathways were adopted during the remediation operations with significant promotive roles of basic background $\mathrm{pH}$. Indeed, Zn removal with TERM consisted mainly in sorptive mechanisms involving exchanges with Ca and $\mathrm{Mg}$ ions, whereas binding onto SBHB was principally achieved through precipitation phenomena.

Keywords: sediment; zinc; removal; hydraulic binders; red muds; adsorption; precipitation

\section{Introduction}

Harboring management and waterways maintenance generate several tons of sedimentary waste [1] that can be implemented as primary resource in different civil engineering applications. Promising options of recycling are now emerging in fields as various as road engineering [2,3] cements and clinkers processing [4], hydraulic binders formulations [5,6] and geopolymers manufacturing $[7,8]$. The reuse of sediments as surrogate component nevertheless faces increasing operational challenges, since intrinsic physico-chemical properties must meet both environmental and mechanical restrictive standards. The release of anthropogenic compounds, namely heavy metals and hydrocarbons, drives indeed several ecosystemic issues through run-offs and ionic diffusion within proximal systems $[9,10]$, whereas the natural organic fraction raises hardening issues during the upgrading process of sediments into engineered by-products [11]. Different remediating processes are 
increasingly investigated to tackle this issue on the basis of pathways such as electrokinetic migration [12-15], microbial redox transformations [16-19] as well as hydrophobic and electrostatic adsorption $[20,21]$. In each of these treatment routes, removal performances appear strongly constrained by sediments inherited properties as well as the configuration of background metrics such as the $\mathrm{pH}$, the Eh and the electrolytes' activity.

In this approach, the emphasis was put on of two eco-friendly materials regarding heavy metals remediation leaning on either the sorptive or the precipitating ways. A negligible proportion of heavy metals in deposits nearing urban zones are attributed to natural processes [22]. They are mostly anthropogenic [23-26] and are now well characterized given their potential outcomes in proximal ecosystems [27,28]. The focus here work was put on zinc $(\mathrm{Zn})$, one of the most recurrent anthropogenic contaminations in sedimentary contexts. It is mostly approached from the angle of suspension/re-deposition mechanisms [29,30] with a focus on the biological effects of its speciation [31]. Indeed, physical (vibrations, gravity disturbances) as well as biological (bioturbation, heterotrophic activities) turbid episodes may alter $\mathrm{Zn}$ redox states and have detrimental impacts on benthic communities [32-35].

The remediation of $\mathrm{Zn}$ mobility is an essential step prior to recycling into any engineering option. Treatment pathways through mechanisms as electrokinetic [12,13], chelation [36], ozonation [37,38] and microbial transformation $[17,18]$ are now extensively studied. We opted here for the sorptive route, classically undertaken with raw phases as zeolites [39] and clay minerals [40,41]. Modified materials e.g., activated carbon [21], carbon nanotubes [42], fullerenes [43,44] or graphene [44,45] are also well-explored. In both cases, adsorbents intrinsic properties namely cations exchange capacity and specific area drive mostly $\mathrm{Zn}$ removal $[46,47]$. Background parameters ( $\mathrm{pH}$, temperature, salinity) govern the magnitude of $\mathrm{Zn}$ /adsorbent associations as well and constrain the typology of preferential chemical bonds.

The objective was to characterize the trapping conditions of $\mathrm{Zn}$ in sediments from three fluvial beds (northern France). A particular attention has been paid to the role of sediments intrinsic property regarding the binding process, and the contribution of a Thermo-Evolved Red Mud (TERM) and a classical hydraulic binder (SBHB) as removing materials were subsequently assessed. Trapping modalities were first studied with a specific attention on sediments' organic compositions, particle distributions and specific areas in order to evaluate the relative influence of these key metrics. In a second step, TERM and SBHB interactions with Zn were performed under pure water conditions with the objective to determine their geochemical pathway of stabilization, and finally, their removal capacity in heavily polluted organo-mineral matrices was assessed through a sequential addition approach. The overall goal was to evaluate the contribution of these two materials regarding the remediation of such fluvial wastes before recycling considerations in circular economy perspectives.

\section{Material and Methods}

\subsection{Interaction Procedure}

\subsubsection{Sediment Spiking}

Sediments were dredged in the rivers of La Deule (Lille, Haut-de-France, France), Aa (Saint-Omer, Haut-de-France, France) and La-Lys (Aire sur La Lys, Haut-de-France, France) between November 2019 and February 2020 (Table 1). Hereafter, they will be named following the location where the dredging operation were undertaken, respectively, Lille, Saint-Omer, and Aire-Sur-la Lys (ASL). Powdery $\mathrm{ZnCl}_{2}$ (Fisher Scientific ${ }^{\circledR}$, Illkirch, France) was used as $\mathrm{Zn}$ source and stabilizers were chosen according to engineering applications purposes. These were a Thermo-Evolved Red Mud (TERM) and a Slag Based Hydraulic Binder (hereafter SBHB) marketed under the denomination Roc $\mathrm{AS}^{\circledR}$. Red muds residues from Gardanne Alumina Plant (France) were used as source materials for TERM. Its thermo-modification (dewatering) and environmental compatibility are described in [48]. 
Table 1. Sediments mineralogical composition, surface area, Total Organic Carbon (TOC) content, Hydrogen Index (HI) and Oxygen Index (OI) measured before Zn spiking and interactions with the two stabilizers.

\begin{tabular}{|c|c|c|c|c|c|c|c|}
\hline Sediments & $\begin{array}{l}\text { Surface Area } \\
\left(\mathrm{m}^{2} \mathrm{~g}^{-1}\right)\end{array}$ & $\begin{array}{l}\text { TOC } \\
(\%)\end{array}$ & $\begin{array}{c}\text { HI } \\
\left(\mathrm{mg} \mathrm{HC} \mathrm{g}^{-1}\right. \\
\text { TOC) }\end{array}$ & $\begin{array}{c}\mathrm{OI} \\
\left(\mathrm{mg} \mathrm{CO} / \mathrm{g}^{-1}\right. \\
\mathrm{TOC})\end{array}$ & $\begin{array}{l}\text { Lipidic } \\
\text { Fraction } \\
\left(\mathrm{mg} \mathrm{g}^{-1}\right)\end{array}$ & $\mathrm{pH}$ & $\begin{array}{l}\text { Main Mineralogical } \\
\text { Content }\end{array}$ \\
\hline Lille & 2.09 & 6.78 & 452 & 98 & 15.89 & 7.8 & $\begin{array}{c}\text { Quartz; Calcite; } \\
\text { Muscovite; Albite; } \\
\text { Orthoclase; Illite; } \\
\text { Montmorillonite }\end{array}$ \\
\hline ASL & 4.69 & 1.15 & 201 & 128 & 1.90 & 7.7 & $\begin{array}{c}\text { Quartz; Calcite; } \\
\text { Orthoclase; Muscovite; } \\
\text { Albite; Diopside }\end{array}$ \\
\hline Saint-Omer & 7.18 & 1.43 & 284 & 119 & 2.36 & 8.1 & $\begin{array}{c}\text { Quartz; Calcite; Brushite; } \\
\text { Muscovite, } \\
\text { Microcline }\end{array}$ \\
\hline
\end{tabular}

$\mathrm{Zn} /$ Sediment interactions were performed using $10 \mathrm{~g}$ of sediment in $100 \mathrm{~mL}$ of ultrapure water with different levels of $\mathrm{Zn}\left(76,38,15,7,0.15\right.$ and $\left.0.015 \mathrm{mmol} \mathrm{L}^{-1}\right)$. For each sediment, this spiking operation was triplicated. Each series was stirred (100 rpm) for $24 \mathrm{~h}$, at which point $10 \mathrm{~mL}$ of aqueous aliquots were taken, filtered $(0.45 \mu \mathrm{m})$ and acidified $\left(\mathrm{HNO}_{3}\right)$ before measurement via Inductively Coupled Plasma-Optical Emission Spectrometry (ICP-OES).

\subsubsection{Stabilization Procedure (Sequential Addition)}

To characterize the stabilizing capacity of TERM and SBHB, the spiked sediments were dried at $45^{\circ} \mathrm{C}$ (7 days), blended with the stabilizers in separate series, homogenized (10 min, $100 \mathrm{rpm}$ ), and completed with $100 \mathrm{~mL}$ of ultrapure water as described in [49]. This operation was performed in triplicates. The mixtures were stirred at $100 \mathrm{rpm}(24 \mathrm{~h})$, and aliquots of $10 \mathrm{~mL}$ were sampled for chemical analysis (ICP OES). The remaining solid mixtures were dried $\left(45^{\circ} \mathrm{C}\right)$ before $X$ ray Diffraction, Thermo-Gravimetric Analysis (TGA) and $X$ ray Fluorescence $(\mathrm{XRF})$ characterizations.

\subsubsection{Adsorbent/Zn Aqueous Interactions}

To better understand the heavy metal's binding mechanisms, interactions with TERM and SBHB experiments were performed in ultrapure water with Liquid/Solid ratio $=10$. Series at $76,38,15,7,0.15$ and $0.015 \mathrm{mmol} \mathrm{L}^{-1}$ of $\mathrm{Zn}$ were prepared in $100 \mathrm{~mL}$ of ultrapure water with10 $\mathrm{g}$ of stabilizer. The blends were agitated during $24 \mathrm{~h}(100 \mathrm{rpm})$ and $10 \mathrm{~mL}$ aliquots were taken to assess elemental concentrations ( $\mathrm{Zn}, \mathrm{Ca}, \mathrm{K}, \mathrm{Mg}, \mathrm{Fe}, \mathrm{Al}, \mathrm{Mn}, \mathrm{S}$ ) using ICP OES. $\mathrm{HCl}(0.1 \mathrm{M})$ was used for $\mathrm{pH}$ adjustments. Solid phases were dried $\left(45^{\circ} \mathrm{C}\right)$ after decantation and finely ground for $\mathrm{XRD}, \mathrm{XRF}$ and TGA characterizations. Ionic strengths' effects were evaluated at constant $\mathrm{Zn}$ concentration $\left(15 \mathrm{mmol} \mathrm{L}^{-1}\right)$ and increasing $\mathrm{NaCl}$ concentrations $\left(1 \times 10^{-3}\right.$ to $\left.1 \mathrm{~mol} \mathrm{~L}^{-1}\right)$. A multi-probe device (conductivity, $\mathrm{pH}$, and redox) was implemented to monitor the electrical conductivity during this experiment.

\subsection{Analytical Methods}

\subsubsection{X-ray Fluorescence}

Bruker S4 Pioneer ${ }^{\circledR}$ spectrometer and a 4-kW wavelength dispersive X-ray fluorescence spectrometer equipped with a rhodium anode were used to characterize the chemical compositions of TERM, SBHB and raw sediments. Measurements were realized at $60 \mathrm{keV}$ and $40 \mathrm{~mA}$ on powdered materials-compressed tablets. Semi-quantitative determination of element concentrations down to the part per million levels was conducted via an integrated standardless evaluation. 


\subsubsection{X-ray Diffraction}

Thoroughly dry powders micronized by grinding in agate mortar and pestle were analyzed using a Bruker D8 Advance diffractometer system via $\mathrm{Co}-\mathrm{K} \alpha$ radiation and a fast Lynx Eye position sensitive detector $(\mathrm{WL}=1.54)$. The diffractometer was used at $35 \mathrm{kV}$ and $40 \mathrm{~mA}$ and scans were performed from $5^{\circ}$ to $80^{\circ} 2 \theta$, with a step interval of $0.02^{\circ} 2 \theta$ and a time acquisition of $96 \mathrm{~s}$ per step. Mineral identification was realized via the BrukerAXS DiffracPlus EVA software and the International Centre for Diffraction Data (ICDD) Powder Diffraction File 2015 database.

\subsubsection{Thermogravimetric Analysis}

Thermogravimetry was implemented as an additional independent technique to quantify minerals decomposition within the raw and treated sediment with the objective to cross-check the mineralogical data (XRD). Analyzes were conducted using a Netzsch STA $449 \mathrm{~F} 3$ Jupiter ${ }^{\circledR}$ thermal analyzer set up at $3^{\circ} \mathrm{C} / \mathrm{min}$ from 40 to $1000^{\circ} \mathrm{C}$ under argon flux.

\subsubsection{Particle Size and Specific Area}

The distribution of adsorbents and sediments particle size was acquired using a LS12330 (ISO 13320-1) laser diffraction Coulter. The specific surface area was obtained by the Brunauer-Emmett-Teller (BET) calculation from nitrogen sorption experiments using an AGITENT Analyzer apparatus from Micromeritics (3FLEX Surface Characterization). Prior to analysis the samples were degassed with a Smart Prep degasser (VacPrep 061) to remove adsorbed compounds and humidity.

\subsubsection{Bulk Organic Matter Characterization}

In order to characterize OM properties, 80 to $140 \mathrm{mg}$ of dried sediments were used for Rock-Eval ${ }^{\circledR} 6$ (Vinci Technologies, Rueil Malmaison, France) analysis. The inert pyrolysis program (first oven) starts with an isothermal stage of $2 \mathrm{~min}$ at $200^{\circ} \mathrm{C}$. Then, the pyrolysis oven temperature is raised at $30^{\circ} \mathrm{C} \mathrm{min}-1$ up to $650{ }^{\circ} \mathrm{C}$ and held $3 \mathrm{~min}$ at this temperature. The oxidation phase (second oven) starts by an isothermal stage at $400{ }^{\circ} \mathrm{C}$ then a ramp at $30^{\circ} \mathrm{C} \mathrm{m^{-1 }}$ up to $850^{\circ} \mathrm{C}$, with a hold for $5 \mathrm{~min}$. The significance of the now classical Rock-Eval parameters was explained by Espitalié et al. [50]. The Hydrogen Index (HI, or $\mathrm{mg} \mathrm{HC} \mathrm{g}^{-1} \mathrm{TOC}$ ) is the amount of $\mathrm{HC}$ released during pyrolysis relative to TOC. The Oxygen Index (OI, or mg CO $\mathrm{C}^{-1} \mathrm{TOC}$ ) is a measure of the oxygen content of the $\mathrm{OM}$ calculated from the amounts of $\mathrm{CO}$ and $\mathrm{CO}_{2}$ released during pyrolysis and normalized to TOC.

\subsubsection{Molecular Analysis}

Sedimentary lipids were extracted using accelerated solvent extraction (ASE 200, Dione $\left.{ }^{\circledR}\right)$ with $\mathrm{CH}_{2} \mathrm{Cl}_{2}: \mathrm{MeOH}(9: 1 \mathrm{v} / \mathrm{v})$ at $100{ }^{\circ} \mathrm{C}$ and 1000 psi. The extract was separated into neutral, acidic and polar fractions using solid phase extraction on aminopropyl bonded silica as described in [51,52]. The acid fraction was methylated with anhydrous $\mathrm{MeOH} / \mathrm{MeCOCl}$ by heating at $60^{\circ} \mathrm{C}$ for $1 \mathrm{~h}$. An internal standard ( $5 \alpha$-cholestane, $\left.100 \mu \mathrm{L}\right)$ was added to each fraction for quantification. Both fractions were analyzed using gas chromatography-mass spectrometry (GC-MS; Trace 1310 GC equipped with AS 3000 autosampler and coupled to an ISQ 7000 mass spectrometer; all from Thermo-Scientific, Bremen, Germany). The GC instrument was fitted with a J\&W-DB5 MS UI column (60 m, $0.25 \mathrm{~mm}$ i.d., $0.25 \mathrm{~mm}$ film thickness) from Agilent Technologies ${ }^{\circledR}$. The oven temperature program was $40^{\circ} \mathrm{C}(1 \mathrm{~min})$ to $120^{\circ} \mathrm{C}$ at $30^{\circ} \mathrm{C} / \mathrm{min}$ and then to $310^{\circ} \mathrm{C}$ (held $40 \mathrm{~min}$ ) at $3{ }^{\circ} \mathrm{C} / \mathrm{min}$. $1 \mu \mathrm{L}$ of each sample was injected in splitless mode at $280^{\circ} \mathrm{C}$ and He was the carrier gas at $1.0 \mathrm{~mL} / \mathrm{min}$. The MS instrument was operated in electron ionization (EI) mode at $70 \mathrm{eV}$ and scanned from $\mathrm{m} / \mathrm{z} 50$ to 650 .

Polycyclic Aromatic Hydrocarbons (PAHs) analyses were carried out with a GC 7820A-5977E MSD, Agilent Technologies, USA equipped with a low polarity capillary column (HP5-MS UI, 30 m, 0.25 mm, $0.25 \mu \mathrm{m}$, Agilent, Santa Clara, CA, USA) with He as 
carrier gas. $2 \mathrm{~g}$ of representative sediment sample were taken Solid/Liquid extraction in dichloromethane. Pulsed splitless injection mode has been used to increase sensitivity. The temperature of the column was held at $45^{\circ} \mathrm{C}$ for $1 \mathrm{~min}$, and then increased from 45 to $80{ }^{\circ} \mathrm{C}$ at $30{ }^{\circ} \mathrm{C} \mathrm{min}-1$. It evolved from 80 to $310^{\circ} \mathrm{C}$ at $7^{\circ} \mathrm{C} \mathrm{min}{ }^{-1}$ with a final isothermal hold at $310^{\circ} \mathrm{C}$ for $10 \mathrm{~min}$. External calibration was performed using 18 PAHs mixture standard (EPA Method 8310 PAH Mixture, Restek, Bellefonte, PA, USA).

\subsubsection{Metal Content Analysis}

$\mathrm{Zn}^{2+}$ aqueous concentrations were assayed through Inductively Coupled Plasma Optical Emission Spectrometry (ICP OES). The implemented device was a 5110 ICP-OES from Agilent Technologies ${ }^{\circledR}$ equipped with an SPS $4^{\circledR}$ autosampler (Agilent technologies).

\subsubsection{Microscopic Observations}

A scanning electron microscope (SEM) type Hitachi S-4300SE/N was implemented for micro-scale characterizations. The device was coupled with Energy Dispersive X-ray Spectrometer (EDS) equipped with a Thermo Scientific Ultra Dry EDS detector in order to perform focalized chemical analysis.

\subsection{Sorption Modeling}

Results were fitted to theoretical models using Langmuir, Freundlich and DubininRadushkevich (DR) equations allowing to precisely quantify the affinity of $\mathrm{Zn}^{2+}$ with the adsorbents. Langmuir model supposes that the adsorbates are retained on individualized sites across the accessible surface, and each site hosts a unique ion. It calculated via the equation [52].

$$
\mathrm{q}_{\mathrm{e}}=\mathrm{q}_{\max } \mathrm{K}_{\mathrm{L}} /\left[1+\left(\mathrm{K}_{\mathrm{L}} \mathrm{C}_{\mathrm{e}}\right)\right]
$$

with: $\mathrm{q}_{\mathrm{e}}$ the adsorbed amount at equilibrium $\left(\mathrm{mol} \mathrm{g}^{-1}\right)$; Ce the concentration of $\mathrm{Zn}^{2+}$ in the solution at equilibrium $\left(\mathrm{mol} \mathrm{L}^{-1}\right)$; $\mathrm{q}_{\max }$ is TERM's maximum sorption capacity; $\mathrm{K}_{\mathrm{L}}$ the Langmuir constant ( $\left.\mathrm{L} \mathrm{mol}^{-1}\right)$;

Freundlich and DR equations admit surface heterogeneities during the adsorption process. Freundlich model is a linear relation that can be expressed through [53].

$$
\ln \mathrm{q}_{\mathrm{e}}=\ln \mathrm{K}_{\mathrm{F}}+1 / \mathrm{n}\left(\ln \mathrm{C}_{\mathrm{e}}\right)
$$

where $\mathrm{K}_{\mathrm{F}}\left(\mathrm{g} \mathrm{L}^{-1}\right)$ and $\mathrm{n}$ are constants and indicate, respectively, the extent of the adsorption and the degree of non-linearity between the metallic ion and the adsorbents. If the term $1 / \mathrm{n}$ ranges between 0.1 and 1 , it suggests that the adsorption mechanism is favorable [54].

DR isotherms permit to deduce complementary thermodynamic parameters. It can be written as:

$$
\ln q_{e}=\ln q m+\beta \times \varepsilon^{2}
$$

where $\varepsilon$ is the Polanyi potential, calculated through the relation (4):

$$
\varepsilon=\mathrm{RT} \ln (1+1 / \mathrm{Ce})
$$

$\mathrm{qm}$ is the theoretical potential saturation capacity of the sorbent and $\beta$ the constant related to the activity $\left(\mathrm{mol}^{2} \mathrm{~J}^{-2}\right)$.

\section{Results and Discussions}

\subsection{Zn Trapping within the Sedimentary Wastes: Magnitude and Pathways}

Bound amounts were assessed with regards of sediments' inorganic and organic properties in order to better understand Zn trapping modalities. From a granulometric point of view, Saint-Omer sediments presented larger volume in the interval between 1 and $100 \mu \mathrm{m}$ (Figure 1A) compared to its sedimentary counterparts. This probably induced the hierarchy of specific areas (Table 1), in which Saint-Omer exhibited higher values $\left(7.18 \mathrm{~m}^{2} \mathrm{~g}^{-1}\right)$ than Lille $\left(2.09 \mathrm{~m}^{2} \mathrm{~g}^{-1}\right)$ and ASL $\left(4.69 \mathrm{~m}^{2} \mathrm{~g}^{-1}\right)$. Therefore, Saint-Omer was 
better predisposed for ionic interactions compared to the other two sediments. In the coarser range $(>100 \mu \mathrm{m})$, no clear hierarchical order distinguished ASL and Lille, while Saint-Omer remained the most endowed in detrital element in this interval as well. Given the low propensity of coarse elements to adsorb metallic ions [55,56], particles distribution above $100 \mu \mathrm{m}$ was not expected to have significant impacts.

A

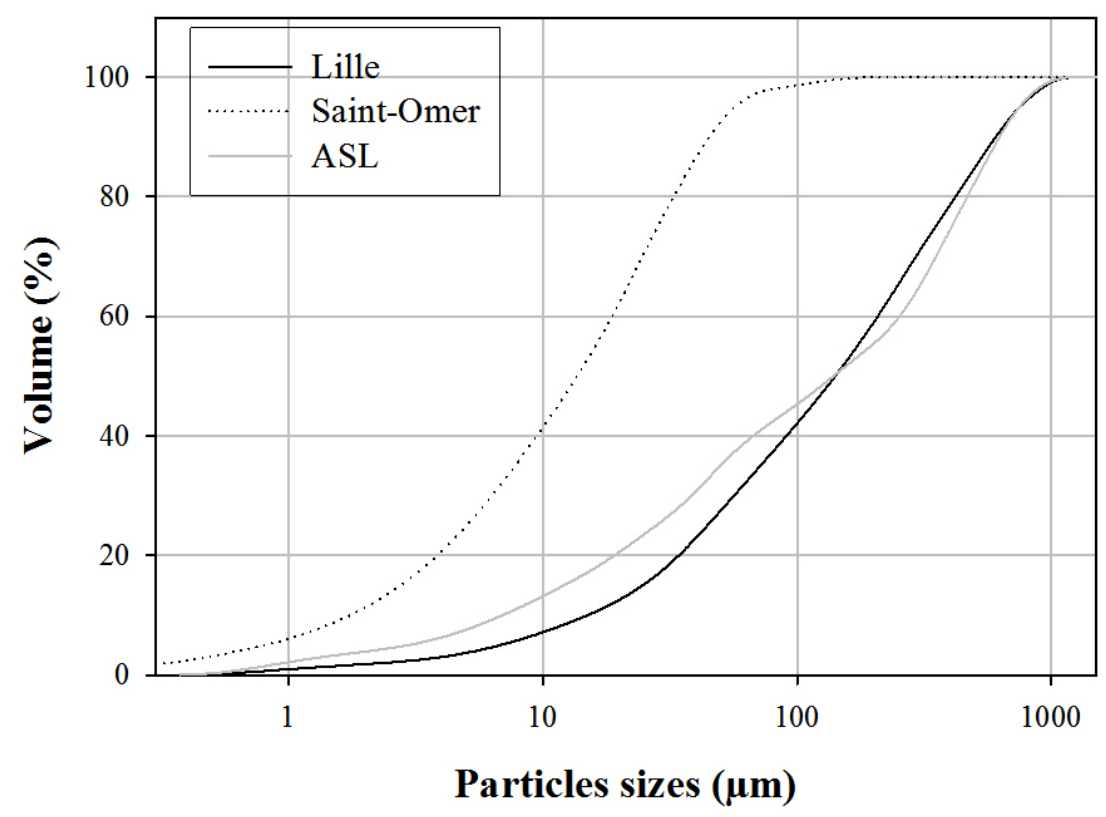

B

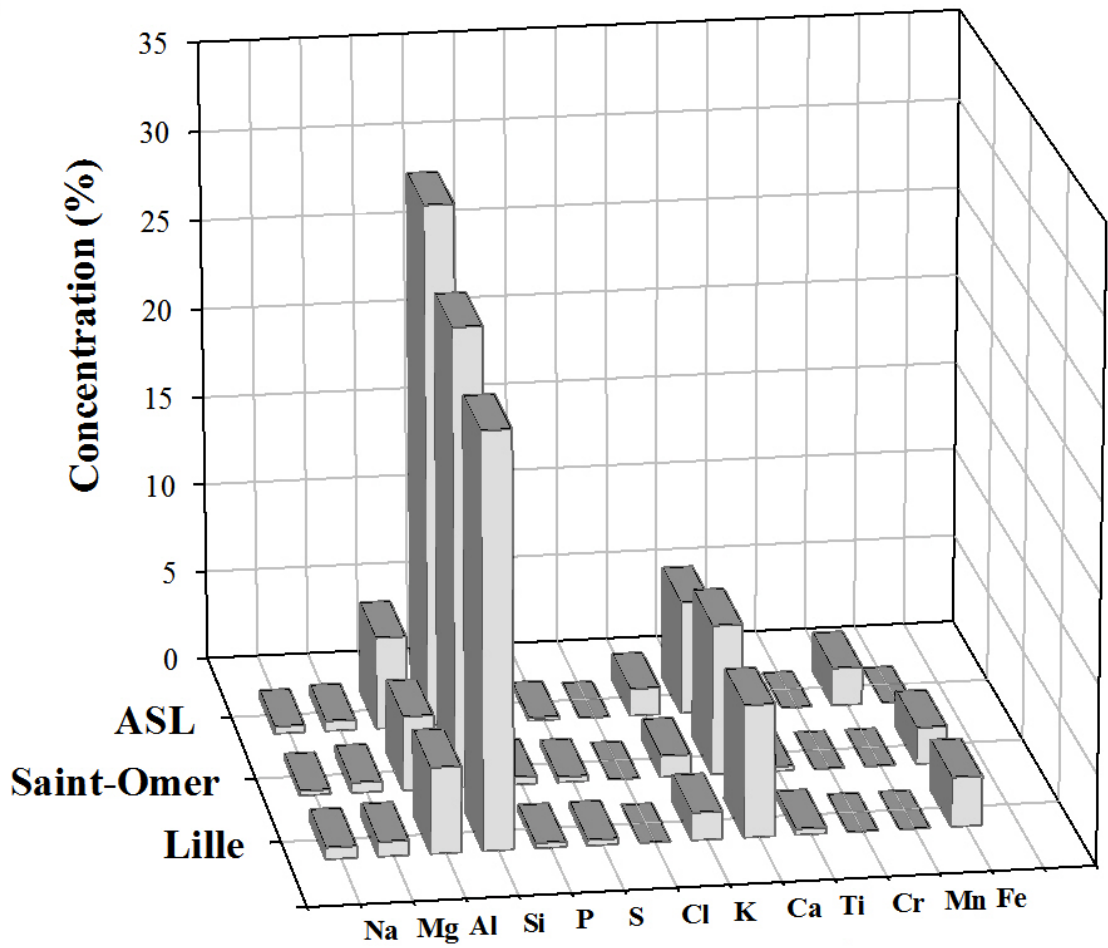

Figure 1. (A) Particle size distribution within the experimented sediments; (B) chemical composition of the three sediments. 
From a mineralogical perspective, the three sediments comprised mainly quartz, albite, orthoclase, and muscovite (Table 1), which were likely the erosive outcome of the $\mathrm{Aa}$, La Deule and La Lys rivers' watersheds. Calcites resulting from intra-water columns' carbonation mechanisms were also highly represented. In addition to these ubiquitous phases, less predominant minerals (clayey phases) distinguished the sedimentary wastes. Even though ASL did not exhibit specific clay patterns, Lille and Saint-Omer presented illite, montmorillonite and brushite. These mineralogical assemblages conferred the thermal behaviors depicted in Figure 2. From 90 to $500{ }^{\circ} \mathrm{C}$, ASL exhibited $4 \%$ of mass loss while Lille and Saint-Omer presented, respectively, $6 \%$ and $3 \%$. Between 500 and $900{ }^{\circ} \mathrm{C}$, Saint-Omer presented higher mass losses (11\%) compared to Lille (6\%) and ASL (5\%). In this range carbonates as calcite are known to undergo important thermal destabilization [57-59].
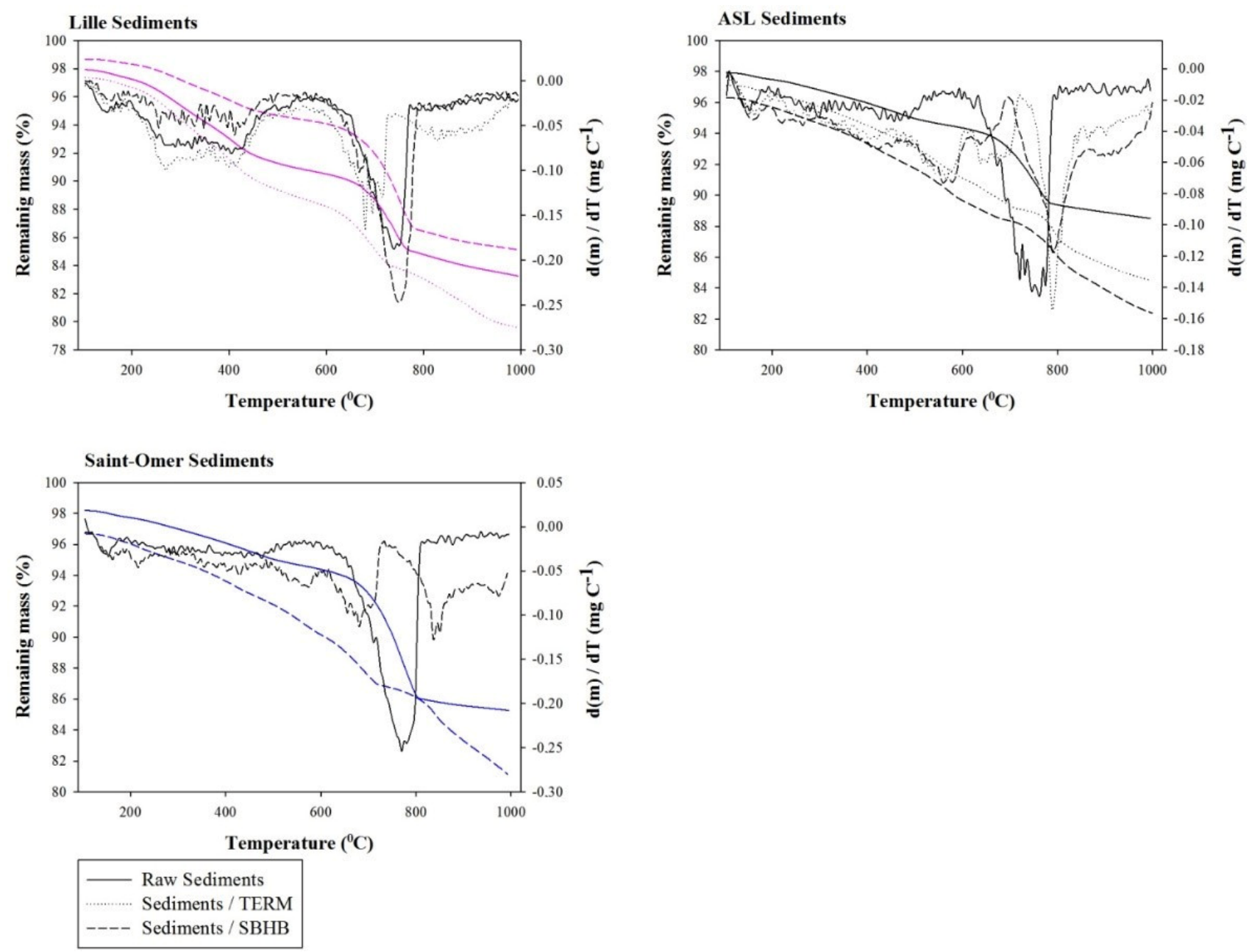

Figure 2. Thermal evolution (TGA) of the three sediments (Lille, Saint-Omer and ASL) before and after stabilization with the Thermo-Evolved Red Mud (TERM) and the Slag Based Hydraulic Binder (SBHB). $\Delta^{*}$ : Mass variations within the raw sediment.

Each organo-mineral ensemble had a specific thermal slope reflecting its own rate of pyrolysis. Mass losses resulted likely from the combination of water molecules destabilization within hydrous minerals, $\mathrm{OM}$ pyrolysis and $\mathrm{CO}_{3}$ losses. The amount of these thermo-sensitive components likely controlled the magnitude of the pre-enumerated mass losses. Higher mass losses in Lille (11\%) can be assigned to larger OM pyrolysis, since this sediment displayed the richest organic content (Table 1). The close OM examination underlined the abundance of natural molecules i.e., Fatty Acids (FAs) and also the occurrence of anthropogenic molecules namely Polycyclic Aromatic Hydrocarbons (PAHs). FAs exhib- 
ited a classical C16 and C18 predominance (Figure 3) highlighting the low state of maturity of the authigenic (phytoplankton, zooplankton, bacteria, archaea) and allogenic organic matter within the three sediments. All carbonaceous lengths together $\left(C_{12}-C_{32}\right)$, FAs were more represented in Lille $\left(74.17 \mu \mathrm{g} \mathrm{g}^{-1}\right)$ compared to Saint-Omer $\left(37.27 \mu \mathrm{g} \mathrm{g}^{-1}\right)$ and ASL $\left(34.21 \mu \mathrm{g} \mathrm{g}^{-1}\right.$ ). Regarding PAHs (Figure 3), fluoranthene and pyrene predominated among the light molecules $\left(\mathrm{M}<203 \mathrm{~g} \mathrm{~mol}^{-1}\right)$, while benzo (b) fluoranthene and benzo (a) pyrene showed strong occurrences among the heavy homologues $\left(\mathrm{M}>203 \mathrm{~g} \mathrm{~mol}^{-1}\right)$. For PAHs also, concentrations were higher in Lille $\left(43 \mu \mathrm{g} \mathrm{g}^{-1}\right)$ compared to Saint-Omer $\left(4 \mu \mathrm{g} \mathrm{g}^{-1}\right)$ and ASL $\left(5.7 \mu \mathrm{g} \mathrm{g}^{-1}\right)$.
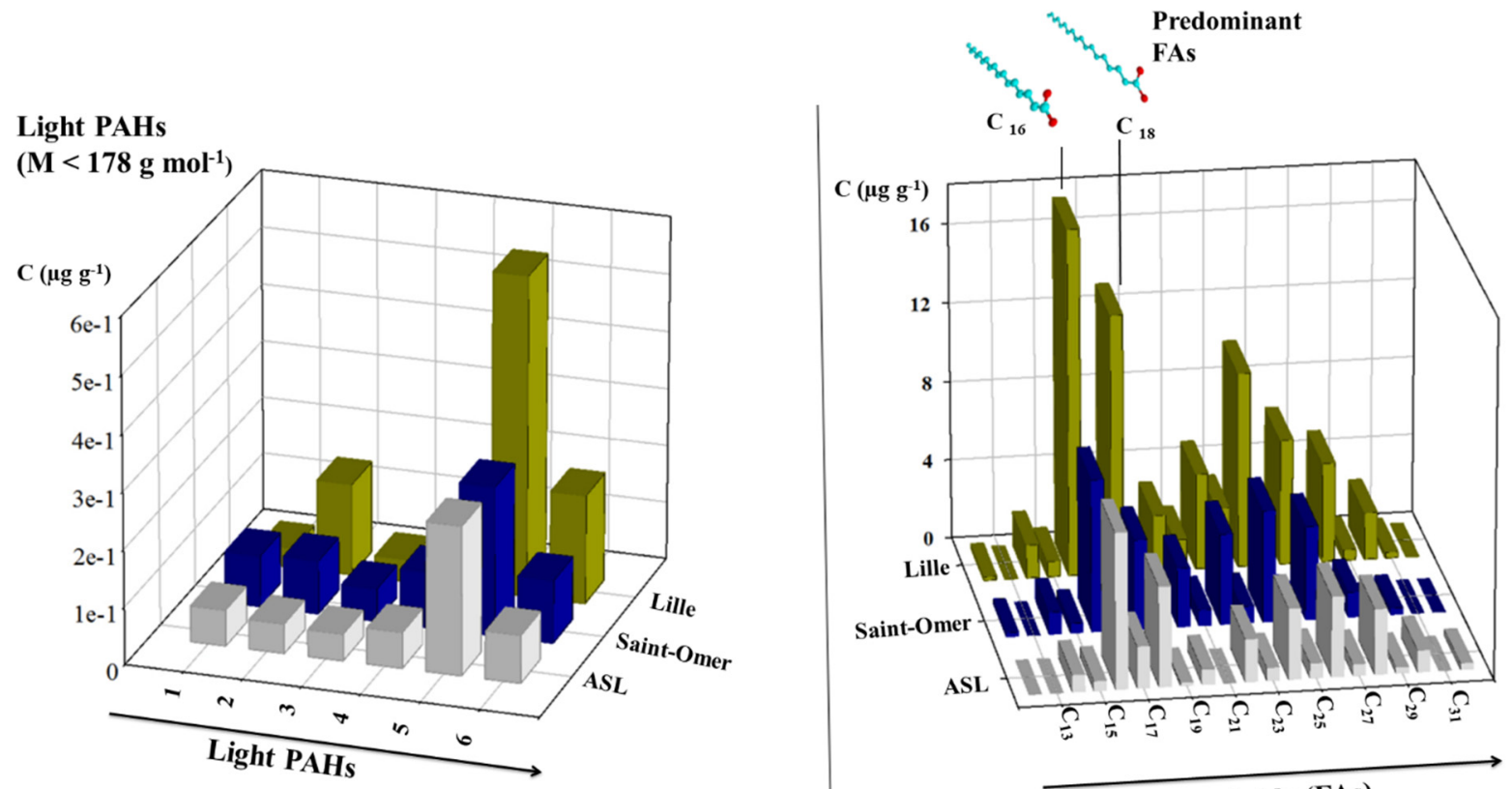

Fatty Acids (FAs)

\section{Heavy PAHs}

$\left(\mathrm{M}>178 \mathrm{~g} \mathrm{~mol}^{-1}\right)$

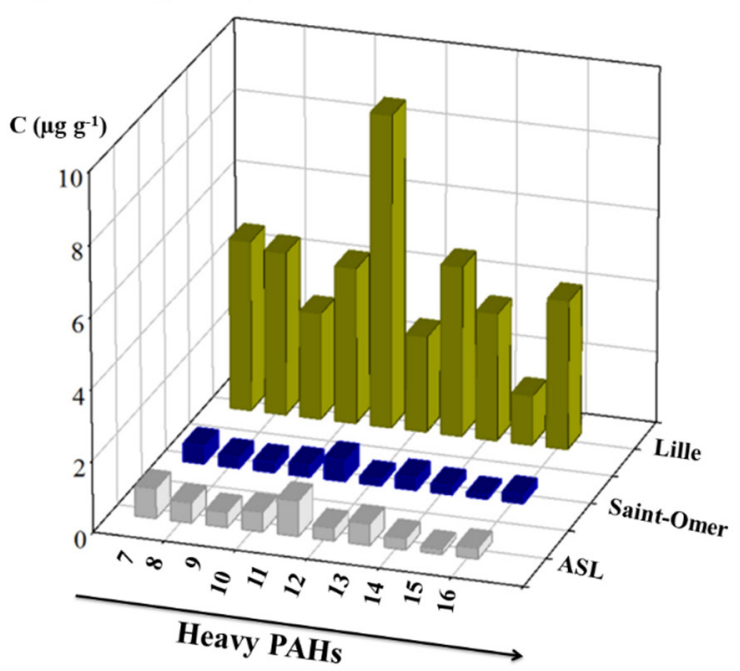

Figure 3. Fatty Acids (FAs) and Polycyclic Aromatic Hydrocarbons (PAHs) distribution within the raw sediments of Lille, Saint Omer and ASL. PAHs assignations: 1 Naphthalene; 2 Acenaphthylene; 3 Acenaphthene; 4 Fluorene; 5 Phenanthrene; 6 Anthracene; 7 Fluoranthene; 8 Pyrene; 9 Benzo (a) anthracene; 10 Chrysene; 11 Benzo (b) fluoranthene; 12 Benzo (k) fluoranthene; 13 Benzo (a) pyrene; 14 Indeno (1,2,3-cd) pyrene; 15 Dibenzo (a,h) anthracene; 16 Benzo (g,h,i) perylene. 
Generally speaking, OM enhances Zn uptake onto organo-mineral matrices [60-62] in both pedological and sedimentary contexts [63,64]. However here, data suggested an opposite tendency. Even though Lille sediments had the highest TOC and HI (Table 1), it did not retain Zn the most (Figure 4). Results underlined indeed, higher propensity of Saint-Omer to trap the metallic element compared to the two other sediments. On the other hand, particulate properties, namely size distribution (Figure 1A), and surface area (Table 1) appeared to have a significant influence on the trapping hierarchy. Indeed, Saint-Omer retained more Zn than Lille and ASL (Figure 4) and presented more favorably predisposed fine particles distribution and surface area magnitudes compared to its counterparts (Table 1).

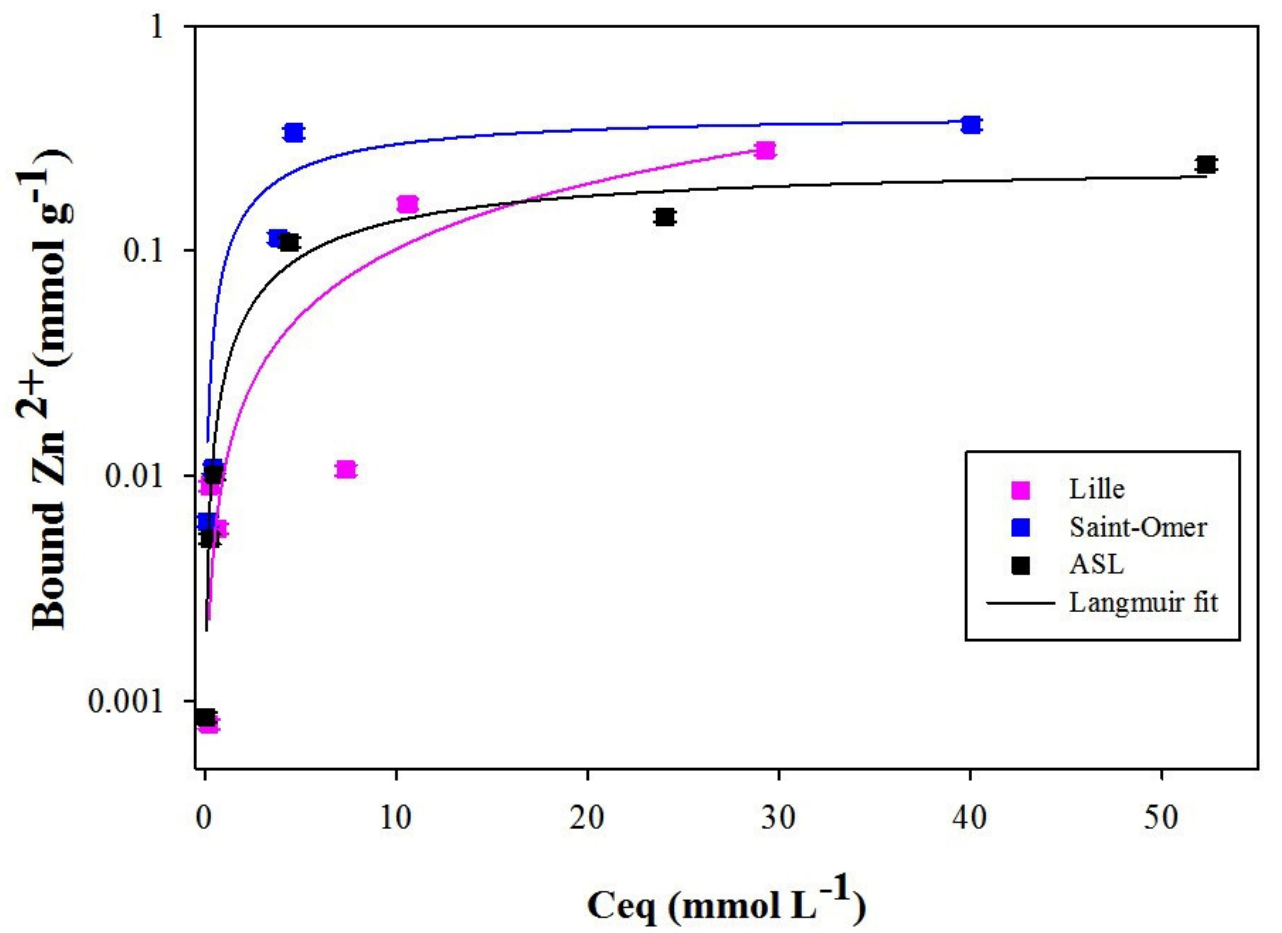

Figure 4. Zn binding onto the three raw sediments.

Furthermore, Saint-Omer exhibited the highest $\mathrm{pH}$ among the tested sediments (Table 1). Therefore, precipitation mechanisms contributed very likely to overall retentions within this sediment, since basic $\mathrm{pH}$ are known to enhance $\mathrm{Zn}$ binding through depositional processes $[65,66]$. So that, it was assumed that alkalization ability and size distributions were more predetermining than OM content regarding $\mathrm{Zn}$ trapping within the experimented sediments.

\subsection{Implementing $S B H B$ and TERM to Lower Zn Release from the Sedimentary Wastes}

Figure 5 shows the release of $\mathrm{Zn}$ from the artificially enriched sediments as a function of stabilizers amount. In Lille sediments, $8 \%$ SBHB reduced $\approx 60 \%$ of initial $\mathrm{Zn}\left(\mathrm{C} / \mathrm{C}_{0}=0.4\right)$, while $16 \%$ TERM were needed to reach similar results (Figure 5A). Likewise in Saint-Omer and ASL sediments, Zn lowering was more efficient with SBHB compared to TERM. In ASL, it took $8 \%$ SBHB to achieve a $60 \%$ decrease $\left(C / C_{0} \approx 0.4\right)$, whereas $20 \%$ TERM was necessary to achieve equivalent lowering percentages (Figure 5B). For Saint-Omer, $12 \%$ of SBHB was required to achieve a $60 \%$ reduction $\left(C / C_{0} \approx 0.4\right)$, while such level was not achievable with TERM on the experimented range (Figure $5 \mathrm{C}$ ). Thus, in all sediments, fewer SBHB amounts were needed to lower the release of Zn. SBHB capacity to raise background $\mathrm{pH}$ and to favor therefore $\mathrm{Zn}$ precipitation drove most likely this tendency. 
A

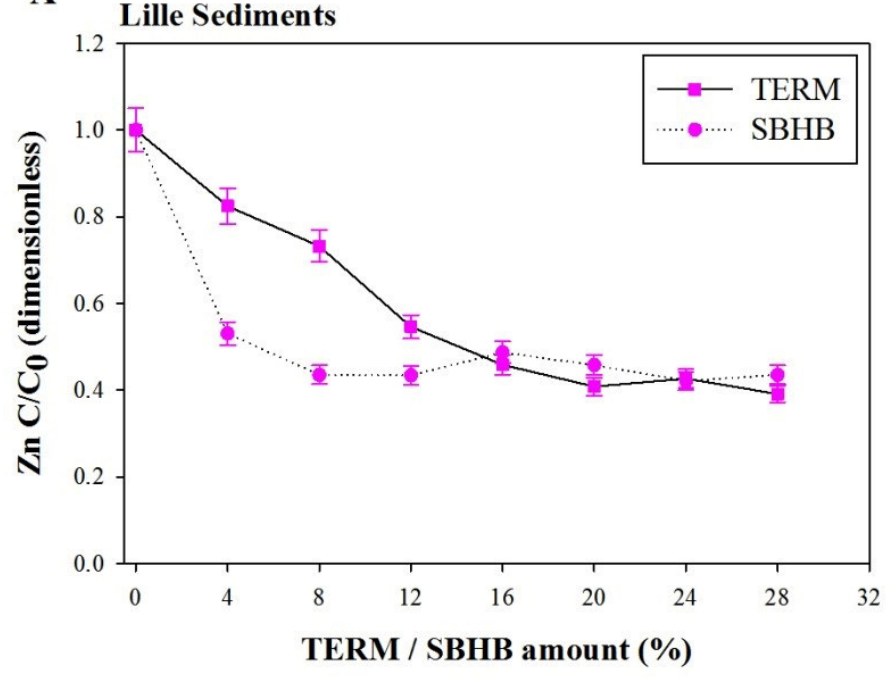

C

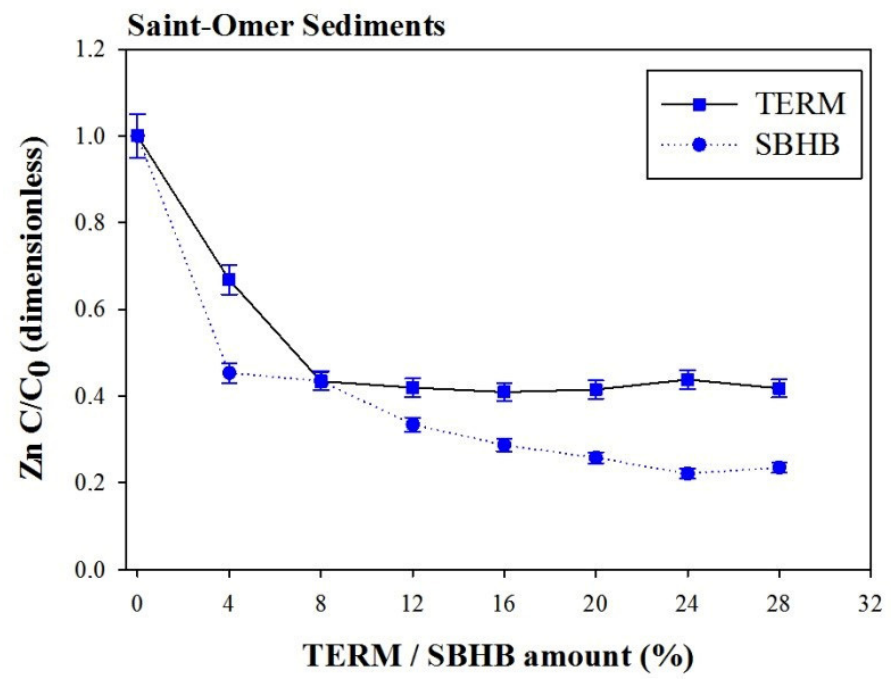

\section{B}

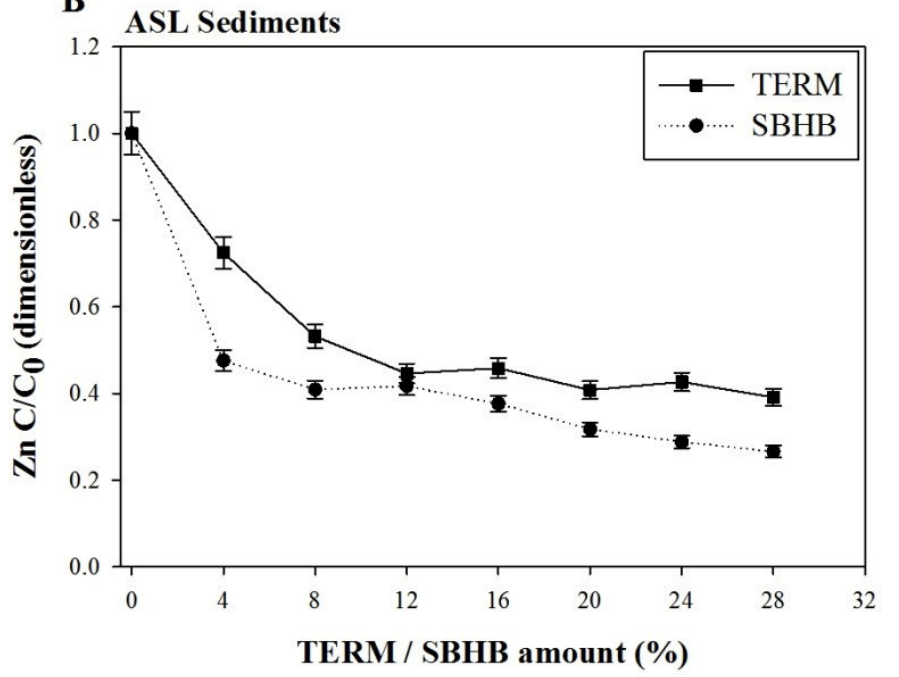

Figure 5. Evolution of $\mathrm{Zn}$ concentration ratios $\left(\mathrm{C} / \mathrm{C}_{0}\right)$ within the studied sediments as a function of stabilizers amount (sequential addition). TERM: Thermo-Evolved Red Mud; SBHB: Slag Based Hydraulic Binder.

Even though SBHB performed globally better than TERM, its effectiveness varied from one sediment to another. Better abatement was indeed, observed in Saint-Omer compared to Lille and ASL. This probably resulted from Saint-Omer's good predisposition to trap the contaminant (Figure 4) and SBHB inhibition in the other two sediments due to high OM concentrations. OM interference on both hardening process and interactive properties of hydraulic binders is indeed a well-known phenomenon [67-72]. Since Lille and ASL were better endowed in OM (Table 1; Figure 3), higher inhibitory effects led very plausibly to poorer SBHB performances.

The affinity of clayey material as TERM with organic molecules is also a well-described mechanism [73-75]. The three sediments here had different contents of organic acids and aromatic compounds (Figure 3), which predisposed each sediment/TERM blend to have a proper Zn evolution. However, no noteworthy differentials were observed above an average TERM amount of $12 \%$. The few differences following sediments' origins occurred below this threshold. In Lille specially, the treatment below $12 \%$ was less performant compared to the two other sedimentary counterparts in equivalent range of TERM addition. 
Competition between $\mathrm{Zn}$ ions and the highly concentrated organic molecules drove very likely this relative lack of performance.

\section{3. $\mathrm{Zn}^{2+}$ Binding onto TERM and SBHB: Mechanisms and Background Effects}

3.3.1. Binding Mechanisms

\section{$\mathrm{Zn} / \mathrm{TERM}$ Interactions}

Figure 6 recapitulates Zn binding isotherms onto TERM and SBHB. Hyperbolic shapes fitting with the Langmuir model (Figure 6A) suggested the reach of a saturation state for TERM, while SBHB displayed a linear evolution (Figure 6C) indicating an ongoing inter-dependency relationship. In the case of TERM, the reach of a hosting sites threshold limited very likely the interaction, while the linear relation in the case of SBHB emphasized the mutual control of $\mathrm{Zn}$ concentrations and SBHB soluble components on the removal mechanism. Modelling parameters showed that TERM data were better fitted with the Langmuir theory than Freundlich and DR equations which exhibited poor $\mathrm{r}^{2}$ (Table 2). The good Langmuir fit corroborated the idea of punctual interaction at TERM's surface since this model assumes singularized sorptions via a unique hosting site [53].
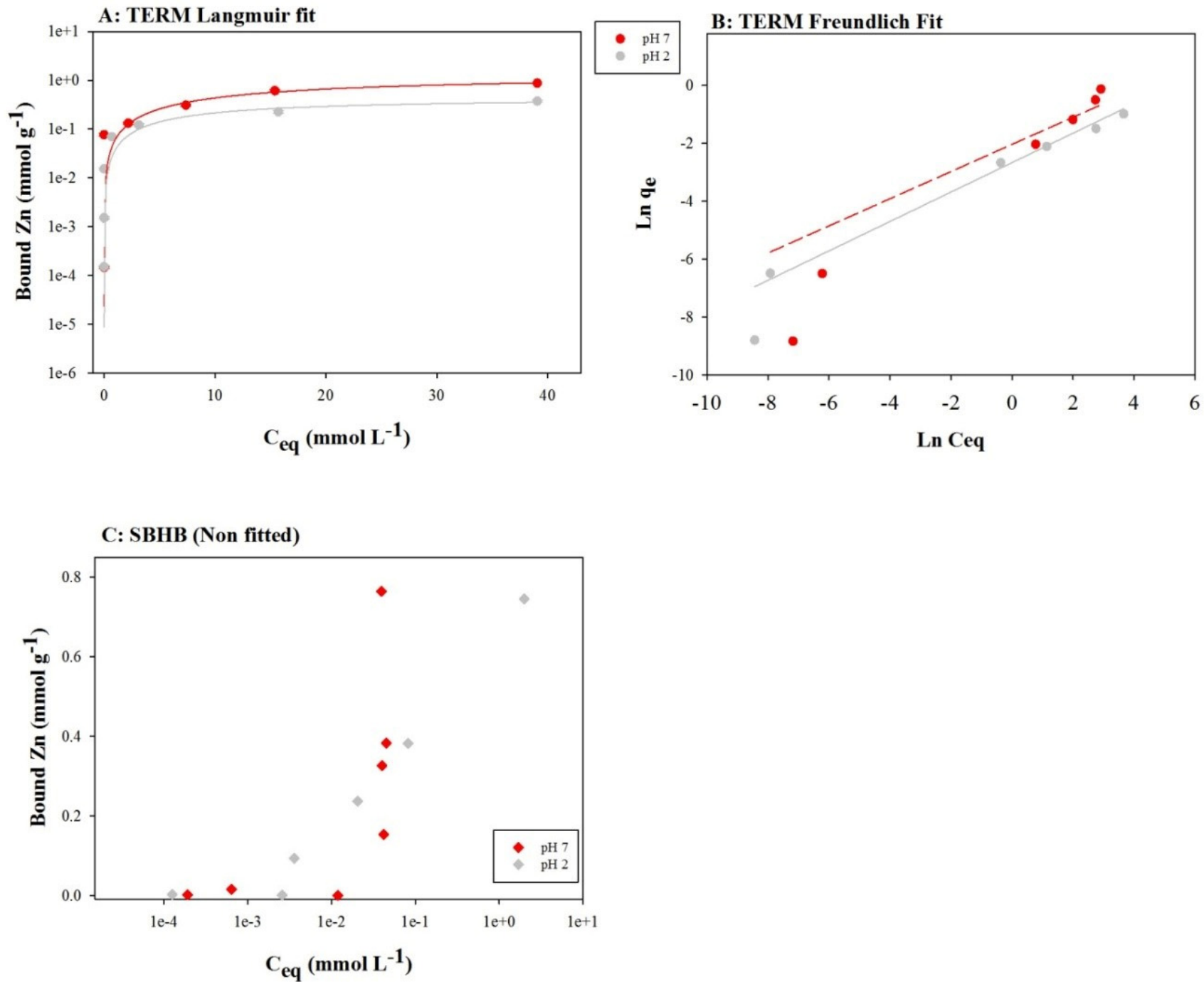

Figure 6. Zn binding on the Thermo-Evolved Red Mud (TERM) and the Slag Based Hydraulic Binder (SBHB). The pH (2 and 7) are for the levels of acidity before aqueous $\mathrm{Zn}^{2+} /$ adsorbents. 
Table 2. Zn binding onto TERM adsorptions parameters ( $\left.\mathrm{q}_{\mathrm{max}}, \mathrm{K}_{\mathrm{L}, \mathrm{F}, \mathrm{D}-\mathrm{R}}\right)$ at $\mathrm{pH} 2$ and $\mathrm{pH} 7$ deduced from Langmuir, Freundlich and Dubinin-Radushkovitch equations.

\begin{tabular}{cccccccccccccc}
\hline & & \multicolumn{3}{c}{ Langmuir } & \multicolumn{3}{c}{ Freundlich } & \multicolumn{4}{c}{ Dubnin-Radushkovitch } \\
\hline & $\mathbf{a}$ & $\mathbf{b}$ & $\mathbf{r}^{\mathbf{2}}$ & $\mathbf{q}$ max & $\mathbf{K}_{\mathbf{L}}$ & $\mathbf{a}$ & $\mathbf{b}$ & $\mathbf{r}^{\mathbf{2}}$ & $\mathbf{K}_{\mathbf{F}}$ & $\mathbf{a}$ & $\mathbf{b}$ & $\mathbf{r}^{\mathbf{2}}$ & $\mathbf{K}_{\mathbf{D R}}$ \\
\hline pH 7 & 0.05 & 0.04 & 0.98 & 15.75 & 1.59 & 0.44 & 2.19 & 0.52 & 0.12 & 0.0006 & -0.97 & 0.66 & 0.38 \\
pH 2 & 0.08 & 0.09 & 0.95 & 12.41 & 0.90 & 0.23 & 0.51 & 0.51 & 0.06 & 0.015 & -1.65 & 0.89 & 0.16 \\
\hline
\end{tabular}

Major elements $(\mathrm{Mg}, \mathrm{Ca}, \mathrm{K}, \mathrm{Na}, \mathrm{Si}, \mathrm{Al})$ behavior provided important indications for the understanding of interactions' preferential pathway (ion exchanges, electrostatic adsorptions etc.). Their evolutions as a function of bound $\mathrm{Zn}$ amounts are depicted in Figure 7. For TERM, aqueous $\mathrm{Mg}$ and Ca increased up to plateau levels at $\simeq 5$ and $\simeq 10 \mathrm{mmol} \mathrm{L}^{-1}$, respectively. Linear growths preceding these saturation thresholds suggested exchange mechanisms between $\mathrm{Mg}$, $\mathrm{Ca}$ and aqueous $\mathrm{Zn}$. Substitution processes of $\mathrm{Zn}$ with elements such as $\mathrm{Ca}$ are, indeed, well-acknowledged within crystalline systems such as Ca-Montmorillonites and calcites.

The reach of the above-mentioned plateaus suggested the cessation of exchanges, resulting likely from $\mathrm{Ca}$ and $\mathrm{Mg}$ supply shortage. This might have also arisen from selectivity phenomena and surrounding cations' competition. The predisposition of $\mathrm{Zn}$ to exchange with $\mathrm{K}$ and $\mathrm{Na}$ is also well-documented. For instance, the early approach of Brigatti et al. [76] showed silicates' (magadiite) good capacity to substitute $\mathrm{K}$ and $\mathrm{Na}$ with background $\mathrm{Zn}$ in aqueous media. This propensity of magadiite to exchange its compositional $\mathrm{Na}^{+}$with $\mathrm{Zn}^{2+}$ in aqueous systems has also been outlined in the approach of Ide et al. [77]. Here in the case of TERM, Na and $\mathrm{K}$ depicted linear evolutions with positive slopes ( 0.7 and 1.06, respectively), suggesting high levels of exchanges with the metallic contaminant. Al concentrations, on the contrary, have lowered with growing $\mathrm{Zn}$ amounts (Figure 7) which suggested a decrease in $\mathrm{Al} / \mathrm{Zn}$ exchanges.

This most probably resulted from the concurrence of more competitive relations such as $\mathrm{Na} / \mathrm{Zn}, \mathrm{Ca} / \mathrm{Zn}$ or $\mathrm{Mg} / \mathrm{Zn}$ substitutions. It might also result from the implication of $\mathrm{Al}$ in additional precipitation mechanisms. Finally, the evolution of aqueous Si with regard of bound $\mathrm{Zn}$ remained constant and did not exhibit a specific trend, probably as a consequence of the high stability of the tetrahedral structures that constitute the modified mud [48].

Beyond these substitution mechanisms, Zn binding via complexation should also be considered. Electrostatic processes involving charged sites on the surface of the adsorbent are indeed well admitted during the interactions of heavy metals with raw versions (nonheated) of equivalent clayey materials.

\section{$\mathrm{SBHB} / \mathrm{Zn}$ Interactions}

Regarding SBHB, the aqueous concentration of most cations $(\mathrm{Mg}, \mathrm{Na}, \mathrm{Si})$ as a function of bound $\mathrm{Zn}$ (Figure 7) remained weakly affected, except for Ca. The latter displayed a linear increase synonym of exchange mechanisms. Al evolution had here also a downward tendency, most probably resulting from more competitive exchanges $(\mathrm{Ca} / \mathrm{Zn})$ and involvement in concurrent precipitations.

Zn higher bindings onto SBHB compared to TERM (Figure 6) suggested the occurrence of further associative processes. Under cementitious basic conditions, the propensity of $\mathrm{Zn}$ to precipitate under oxides/hydroxides and/or calcium zincate] is well-acknowledged. The commonly admitted pathway requires the hydrolysis of cementitious phases which allows the formation of calcium zincates $\left(\mathrm{Ca} \mathrm{Zn}_{2}(\mathrm{OH})_{6} 2 \mathrm{H}_{2} \mathrm{O}\right)$, whereas oxides $(\mathrm{ZnO})$ and hydroxides $\left(\mathrm{ZnOH}_{2}\right)$ precipitate as a respond to the classical constraints of Pourbaix $(\mathrm{pH} /$ redox). Here, SEM/EDS observations performed after SBHB/Zn interactions (Figure 8) pointed out the occurrence of such precipitates. The observations stressed out indeed, the presence of precipitates with predominant $\mathrm{Zn}$ in addition to the typically cementitious silicates and slag debris (Figure 8). Zn precipitates were preferentially deposited around silicates grains and exhibited needle-like morphologies. 
In cementitious contexts, such Zn-based elongated shapes were reported as Zn-oxides and hydroxides. Furthermore, hexagonal geometries characterize Ca-zincates, which comfort the idea that the needle-like deposits were oxides and hydroxides. Thus, a high proportion of SBHB bound $\mathrm{Zn}$ arose very likely from precipitation phenomena in addition to the cation substitutions previously mentioned.
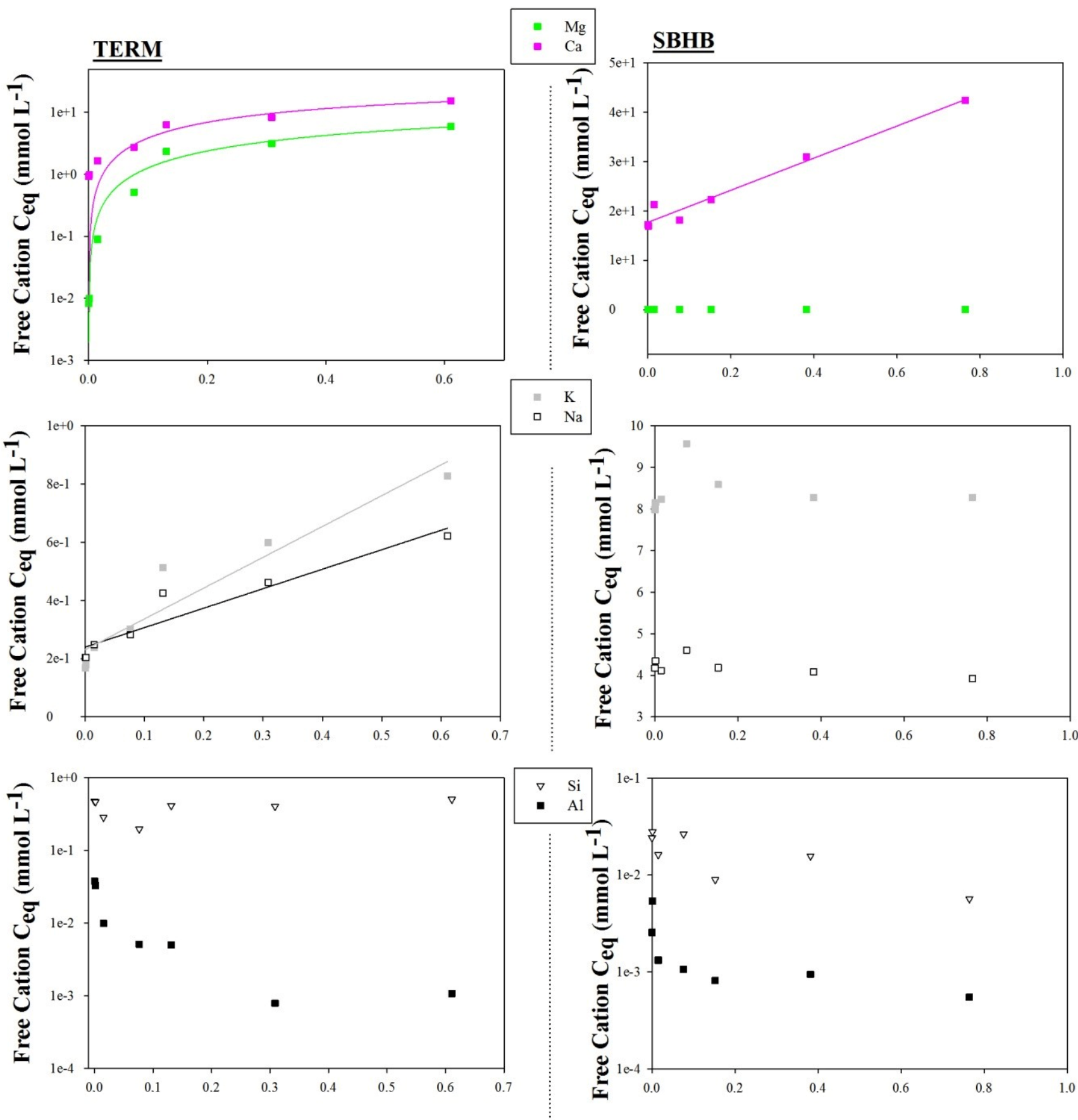

\section{Bound $\mathrm{Zn}^{2+}(\mathrm{mmol} \mathrm{g}-1)$}

Figure 7. Major elements ( $\mathrm{Mg}, \mathrm{Ca}, \mathrm{K}, \mathrm{Na}, \mathrm{Si}, \mathrm{Al})$ concentrations at equilibrium as a function of bound $\mathrm{Zn}$ for the ThermoEvolved Red Mud (TERM) and the Slag Base Hydraulic Binder (SBHB). 

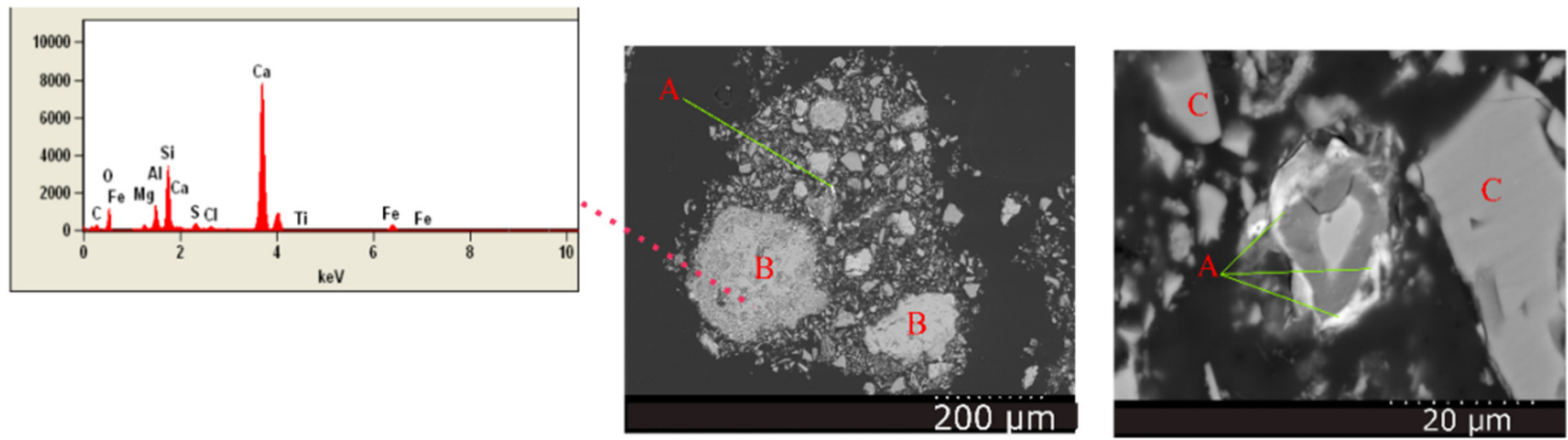

Legend

A: Zinc precipitates

B: Calcium Silicate

(cementious phase)

C: Slag debris
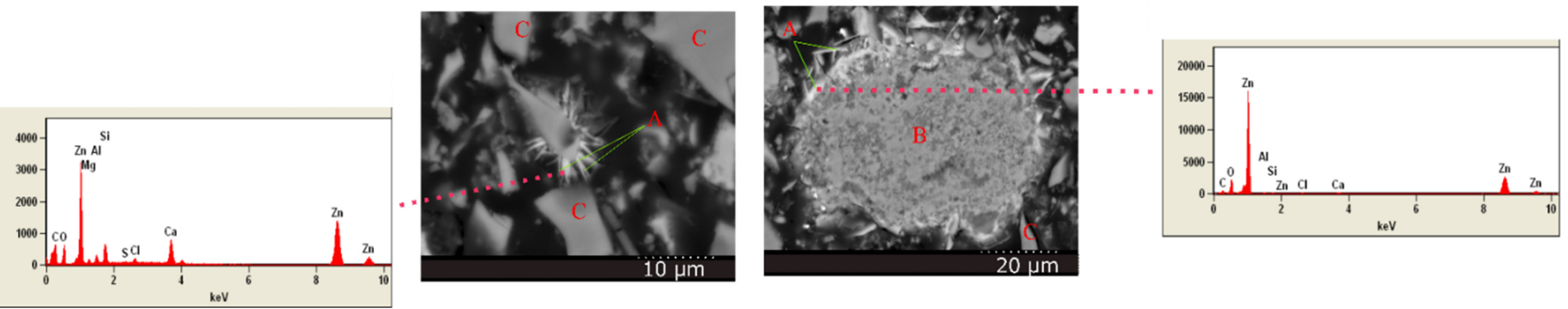

Figure 8. Microscopic characterizations (SEM/EDS) of the Slag Based Hydraulic Binder (SBHB) after interaction with zinc solution. 


\subsubsection{Background (pH and Ionic Strength) Effects}

Several studies showed the efficiency of metallic cation's uptake with growing basicity. For instance, Oren and Kaya [65] reported that the most favorable acido-basic configuration for $\mathrm{Zn}$ removal with zeolites was around $\mathrm{pH}$ 8. Similarly, Sen and Gomez [66] removed higher $\mathrm{Zn}$ amounts with bentonites under basic settings $(\mathrm{pH}=7.6)$. Likewise, the removal capacities of hydroxyapatite, Kaolin, fly ash, calcite and biochar were reported more favorable under basic backgrounds. Here, a hierarchy consistent with this bibliographical trend was observed for both TERM and SBHB (Figure 6). For TERM whose behavior was compatible with adsorption models, $\mathrm{q}_{\max }$ magnitudes emphasized the antagonism between background acidity and $\mathrm{Zn}$ binding. Indeed, $\mathrm{q}_{\max }$ values were 15.75 and $12.41 \mathrm{mmol} \mathrm{g}^{-1}$ at, respectively, $\mathrm{pH} 7$ and $\mathrm{pH}$ 2, confirming more favorable $\mathrm{Zn}$ uptakes when $\mathrm{pH}$ heightens (Table 2).

A plausible explanation for this hierarchy was the increase of hydroxyl ions' activity during the transition from $\mathrm{pH} 2$ to 7 . Hydroxyls activity promoted very likely $\mathrm{Zn}$ precipitation contributing de facto to the overall removal for TERM. Thus, $\mathrm{Zn}$ binding must be interpreted as a cumulative phenomenon resulting from both ionic exchanges $(\mathrm{Ca}, \mathrm{Mg}, \mathrm{Na}$, $\mathrm{K})$ as seen above, and mineral precipitation (oxides and hydroxides). Regarding SBHB, binding was also more intense at $\mathrm{pH} 7$ (Figure 6). Growing basicity promoted precipitation, while ionic exchanges involving Ca solely (Figure 7) remained very likely a mechanism of second importance. Indeed, SEM/EDS evaluations did not point out traces of $\mathrm{Zn}$ in silicate grains and/or slag debris (see examples in Figure 8), which argued in favor of poor retentions through ionic exchanges.

The evolution of bound $\mathrm{Zn}$ for both TERM and SBHB as a function of salts concentrations highlighted the promoting influence of ionic strengths up to a threshold value $\left(\approx 2 \mathrm{mmol} \mathrm{L}^{-1}\right)$, above which the removal depicted a saturating trend. This removal had however, to be interpreted with caution since $\mathrm{ZnCl}_{2}$ precipitation might occur with growing $\mathrm{Cl}^{-}$activity ( $\mathrm{NaCl}$ dissolution). This was all the more plausible given that increasing ionic forces were assumed in the literature to be a detrimental factor for heavy metal removal.

\section{Conclusions}

$\mathrm{Zn}$ trapping modalities in fluvial sediments was examined, before assessing the contribution of two eco-friendly clayey materials (TERM, SBHB) as remediating options. The overall purpose was to improve the environmental compatibility of these river sediments in order to promote their reuse in engineering processes.

Spiking approaches showed that the richest sediment (Lille) in terms of TOC, fatty acids and aromatic molecules did not significantly bound $\mathrm{Zn}$ compared to its counterparts. On the other hand, binding appeared particularly efficient within the sediment with the highest $\mathrm{pH}$ and specific area (Saint-Omer), suggesting that medium alkalinization and particle size were more determinant than organic content.

Even though organic matter did not have a preeminent role during the trapping process, it nevertheless displayed a significant influence during the treatment operations conducted with SBHB and TERM. Indeed, poorer performance was observed for the most organic sediment (Lille) at low SBHB and TERM amounts $(<12 \%)$. Above this threshold $(12 \%)$, both stabilizers allowed good Zn lowering, as $80 \%$ of release was avoid under the best settings.

Batch approaches suggested that removals with the modified mud (TERM) occurred mainly via ionic exchange $(\mathrm{Ca}, \mathrm{Mg}, \mathrm{Na}, \mathrm{K})$ and, in a lesser extent, through $\mathrm{pH}$-sensitive precipitation phenomena. This sorptive treatment enhanced the environmental compatibility of the experimented organo-mineral ensemble and can contribute to the consideration of alike matrices as resource in engineering techniques.

Author Contributions: Conceptualization, A.M.A., methodology, A.M.A. and C.L.M.; formal analysis, A.M.A. and W.M.; funding acquisition, M.B. and N.-E.A. All authors have read and agreed to the published version of the manuscript. 
Funding: This research received no external funding.

Institutional Review Board Statement: Not applicable.

Informed Consent Statement: Not applicable.

Acknowledgments: This study has been supported by the project SEDIASPHALTE and benefited of E.U funds (FEDER).The authors are grateful to Johanna Caboche, Guillaume Pothier and Damien Bertrancourt from IMT Lille-Douai for their technical help. We are also thankful to Rachel Boscardin (ISTO) for her analytical contribution.

Conflicts of Interest: The authors declare no conflict of interest.

\section{References}

1. Dubois, V.; Abriak, N.E.; Zentar, R.; Ballivy, G. The use of marine sediments as a pavement base material. Waste Manag. 2009, 29, 774-782. [CrossRef]

2. Miraoui, M.; Zentar, R.; Abriak, N.E. Road material basis in dredged sediment and basic oxygen furnace steel slag. Constr. Build. Mater. 2012, 30, 309-319. [CrossRef]

3. Wang, D.X.; Abriak, N.E.; Zentar, R.; Xu, W.Y. Solidification/stabilization of dredged marine sediments for road construction. Environ. Technol. 2012, 33, 95-101. [CrossRef]

4. Faure, A.; Coudray, C.; Anger, B.; Moulin, I.; Colina, H.; Izoret, I.; Théry, F.; Smith, A. Beneficial reuse of dam fine sediments as clinker raw material. Constr. Build. Mater. 2019, 218, 365-384. [CrossRef]

5. Dang, T.A.; Kamali-Bernard, S.; Prince, W.A. Design of new blended cement based on marine dredged sediment. Constr. Build. Mater. 2013, 41, 602-611. [CrossRef]

6. Benzerzour, M.; Amar, M.; Abriak, N.E. Design of new blended cement based on marine dredged sediment. Constr. Build. Mater. 2017, 140, 432-444. [CrossRef]

7. Ferone, C.; Colangelo, F.; Cioffi, R.; Montagnaro, F.; Santoro, L. Use of reservoir clay sediments as raw materials for geopolymer binders. Adv. Appl. Ceram. 2013, 112, 184-189. [CrossRef]

8. Lirer, S.; Liguori, B.; Capasso, I.; Flora, A.; Caputo, D. Mechanical and chemical properties of composite materials made of dredged sediments in a fly-ash based geopolymer. J. Environ. Manag. 2017, 19, 1-7. [CrossRef]

9. Liu, M.; Zhong, J.; Zheng, X.; Yu, J.; Liu, D.; Fan, C. Fraction distribution and leaching behavior of heavy metals in dredged sediments disposal sites around Meuliang Bayn Lake Taihu (China). Environ. Sci. Pollut. Res. 2018, 25, 9737-9744. [CrossRef]

10. O'Shea, F.; Cundy, A.B.; Spencer, K.L. Contaminant legacy from historic coastal landfills and their potential as source of diffuse pollution. Mar. Pollut. Bull. 2018, 128, 446-455. [CrossRef]

11. Zentar, R.; Abriak, N.E.; Dubois, V. Effects of salts and organic matter on Atterberg limits of dredged marine sediments. Appl. Clay Sci. 2009, 42, 391-397. [CrossRef]

12. Altaee, A.; Smith, R.; Mikhalovsky, S. The feasibility of decontamination of reduced saline sediments from copper using the electrokinetic process. J. Environ. Manag. 2008, 88, 1611-1618. [CrossRef]

13. Rozas, F.; Castellote, M. Electrokinetic remediation of dredged sediments polluted with heavy metals with different enhancing electrolytes. Electrochim. Acta 2012, 86, 102-109.

14. Massi, M.; Ceccarini, A.; Iannelli, R.; Iannelli, R. Model Electrokinetic remediation of dredged sediments polluted with heavy metals with different enhancing electrolytes. -based optimization of field-scale electrokinetic treatment of dredged sediments. Chem. Eng. J. 2017, 328, 87-97. [CrossRef]

15. Benamar, A.; Tian, Y.; Portet-Koltalo, F.; Ammami, M.T.; Giusti-Petrucciani, N.; Song, Y.; Boulangé-Lecomte, C. Enhanced electrokinetic remediation of multi-contaminated dredged sediments and induced effect on their toxicity. Chemosphere 2019, 228, 744-755. [CrossRef]

16. De Almeida Neto, A.F.; Vieira, M.G.A.; da Silva, M.G.C. Adsorption and desorption processes for copper removal from water using different eluents and calcined clay as adsorbent. J. Water Process. Eng. 2014, 3, 90-97. [CrossRef]

17. Kwon, H.K.; Jeon, J.Y.; Oh, S.J. Potential for Heavy Metal (Copper and Zinc) Removal from Contaminated Marine Sediments using Microalgae and Light Emitting Diodes. Ocean Sci. J. 2017, 52, 57-66. [CrossRef]

18. Nastro, R.A.; Gambino, E.; Toscanesi, M.; Arienzo, M.; Ferrara, L.; Trifuoggi, M. Microbial Fuel Cells (MFCs) Remediation Activity of Marine Sediments Sampled at a Dismissed Industrial Site: What Opportunities? J. Clean. Prod. 2019, 235, 1559-1566. [CrossRef]

19. Mahamat Ahmat, A.; Mamindy-Pajany, Y. Over-sulfated soils and sediments treatment: A brief discussion on performance disparities of biological and non-biological methods throughout the literature. Waste Manag. Res. 2021, 39, 528-545. [CrossRef]

20. Choi, H.J.; Yu, S.W.; Kim, K.H. Efficient use of Mg-modified zeolite in the treatment of aqueous solution contaminated with heavy metal toxic ions. J. Taiwan Inst. Chem. Eng. 2016, 63, 482-489. [CrossRef]

21. Burakov, A.E.; Galunin, E.V.; Burakova, I.V.; Kucherova, A.E.; Agarwal, S.; Tkachev, A.G.; Gupta, V.K. Adsorption of heavy metals on conventional and nanostructured materials for wastewater treatment purposes: A review. Ecotoxicol. Environ. Saf. 2018, 148, 702-712. [CrossRef] 
22. Windom, H.L.; Schropp, S.J.; Calder, F.D.; Ryan, J.D.; Smith, R.G., Jr.; Burney, L.C.; Lewis, F.G.; Rawlinson, C.H. Natural Trace Metal Concentrations in Estuarine and Coastal Marine Sediments of the Southeastern United States. Environ. Sci. Technol. 1989, 23, 314-320. [CrossRef]

23. Bhuyan, M.S.; Bakar, M.A.; Akhtar, A.; Hossain, M.B.; Ali, M.M.; Islam, M.S. Heavy metal contamination in surface water and sediment of the Meghna River, Bangladesh. Environ. Nanotechnol. Monit. Manag. 2017, 8, 273-279. [CrossRef]

24. Vu, C.T.; Lin, C.; Shern, C.C.; Yeh, G.; Le, V.G.; Tran, H.T. Contamination, ecological risk and source apportionment of heavy metals in sediments and water of a contaminated river in Taiwan. Ecol. Indic. 2017, 82, 32-42. [CrossRef]

25. Jacquiod, S.; Cyriaque, V.; Riber, L.; As-Soud, W.A.; Gillan, D.C.; Wattiez, R.; Sorensen, S.J. Long-term industrial metal contamination unexpectedly shaped diversity and activity response of sediment microbiome. J. Hazard. Mater. 2018, 344, $299-307$. [CrossRef]

26. Pandey, L.K.; Park, J.; Son, D.H.; Kim, W.; Islam, M.S.; Choi, S.; Lee, H.; Han, T. Assessment of metal contamination in water and sediments from major rivers in South Korea from 2008 to 2015. Sci. Total Environ. 2019, 651, 323-333. [CrossRef] [PubMed]

27. Saher, N.U.; Sidiqqui, A.S. Occurrence of heavy metals in sediment and their bioaccumulation in sentinel crab (Macrophthalmus depressus) from highly impacted coastal zone. Chemosphere 2019, 221, 89-98. [CrossRef] [PubMed]

28. Paches, M.; Martinez-Guijarro, R.; Aguado, D.; Ferrer, J. Assessment of the impact of heavy metals in sediments along the Spanish Mediterranean coastline: Pollution indices. Environ. Sci. Pollut. Res. 2019, 26, 10887-10901. [CrossRef]

29. Vidal-Durà, A.; Burke, I.T.; Stewart, D.I.; Mortimer, R.J.G. Reoxidation of estuarine sediments during simulated resuspension events: Effects on nutrient and trace metal mobilization. Estuar. Coast. Shelf Sci. 2018, 207, 40-55. [CrossRef]

30. Richards, C.M.; van Puffelen, J.L.; Pallud, C. Effects of sediment resuspension on the oxidation of acid-volatile sulfides and release of metals (iron, manganese, zinc) in pescadero estuary (CA, USA). Environ. Toxicol. Chem. 2017, 37, 993-1006. [CrossRef]

31. Xie, M.; Alsina, M.A.; Yuen, J.; Packman, A.I.; Gaillard, J.F. Effects of resuspension on the mobility and chemical speciation of zinc in contaminated sediments. J. Hazard. Mater. 2019, 364, 300-308. [CrossRef]

32. Cervi, E.C.; Hudson, M.; Rentschler, A.; Burton, G.A. Metal Toxicity During Short-Term Sediment Resuspension and Redeposition in a Tropical Reservoir. Environ. Toxicol. Chem. 2019, 38, 1476-1485. [CrossRef] [PubMed]

33. Ciutat, A.; Boudou, A. Bioturbation effects on cadmium and zinc transfers from a contaminated sediment and on metal bioavailability to benthic bivalves. Environ. Toxicol. Chem. 2003, 22, 1574-1581. [CrossRef]

34. Schaller, J. Bioturbation/bioirrigation by Chironomus plumosus as main factor controlling elemental remobilization from aquatic sediments? Chemosphere 2014, 107, 336-343. [CrossRef]

35. He, Y.; Men, B.; Yang, X.; Li, Y.; Xu, H.; Wang, D. Relationship between heavy metals and dissolved organic matter released from sediment by bioturbation/bioirrigation. J. Environ. Sci. 2019, 75, 216-223. [CrossRef]

36. Vandevivere, P.; Hammes, F.; Verstraete, W.; Feijtel, T.; Schowanek, D. Metal Decontamination of Soil, Sediment, and Sewage Sludge by Means of Transition Metal Chelant S,S.-EDDS. J. Environ. Eng. 2001, 127, 802-811. [CrossRef]

37. Meegoda, J.N.; Batagoda, J.H.; Aluthgun-Hewage, S. Briefing: In situ decontamination of sediments using ozone nanobubbles and ultrasound. J. Environ. Eng. Sci. 2017, 1, 1-3. [CrossRef]

38. Batagoda, J.H. Decontamination of the Passaic River Sediments Using Ultrasound with Ozone Nano-Bubbles. Ph.D. Thesis, New Jersey Institute of Technology, Newark, NJ, USA, 2018. Available online: https://digitalcommons.njit.edu/dissertations/1368 (accessed on 3 September 2021).

39. Rad, L.R.; Momeni, A.; Ghazani, B.F.; Irani, M.; Mahmoudi, M.; Noghreh, B. Removal of $\mathrm{Ni}^{2+}$ and Cd $\mathrm{Cd}^{2+}$ ions from aqueous solutions using electrospun PVA/zeolite nanofibrous adsorbent. Chem. Eng. J. 2014, 256, 119-127. [CrossRef]

40. Altin, O.; Özbelge, H.O.; Dogu, T. Use of general purpose adsorption isotherms for heavy metal metal-clay mineral interactions. J. Colloid Interface Sci. 1998, 198, 130-140. [CrossRef]

41. Bertagnolli, C.; Kleinübing, S.J.; da Silva, M.G.C. Preparation and characterization of a Brazilian bentonite clay for removal of copper in porous beds. Appl. Clay Sci. 2011, 53, 73-79. [CrossRef]

42. Gupta, V.K.; Moradi, O.; Tyagi, I.; Agarwal, S.; Sadegh, H.; Shahryari-Ghoshekandi, R.; Garshasbi, A. Study on the removal of heavy metal ions from industry waste by carbon nanotubes: Effect of the surface modification: A review. Crit. Rev. Environ. Sci. Technol. 2015, 46, 93-118. [CrossRef]

43. Lucena, R.; Simonet, B.M.; Cárdenas, S.; Valcárcel, M. Potential of nanoparticles in sample preparation. J. Chromatogr. A 2011, 1218, 620-637. [CrossRef]

44. Huang, Z.H.; Zheng, X.; Lv, W.; Wang, M.; Yang, Q.H.; Kang, F. Adsorption of Lead (II) Ions from Aqueous Solution on Low-Temperature Exfoliated Graphene Nanosheets. Langmuir 2011, 27, 7558-7562. [CrossRef] [PubMed]

45. Cong, H.P.; Ren, X.C.; Wang, P.; Yu, S.H. Macroscopic Multifunctional Graphene-Based Hydrogels and Aerogels by a Metal Ion Induced Self-Assembly Process. ACS Nano 2012, 6, 2693-2703. [CrossRef] [PubMed]

46. Singh, S.P.; Ma, L.Q.; Harris, W.G. Heavy Metal Interactions with Phosphatic Clay. J. Environ. Qual. 2001, 30, 1961-1968. [CrossRef]

47. Krikorian, N.; Martin, D.F. Extraction of Selected Heavy Metals Using Modified Clays. J. Environ. Sci. Health Part A 2005, 40, 601-608. [CrossRef]

48. Scribot, C. Etude du Potentiel de Valorisation de la Bauxaline®en Matériaux de Construction et de Dépollution. Ph.D. Thesis, Lille University, Lille, France, 2017; p. 227.

49. Mahamat Ahmat, A.; Mamindy-Pajany, Y.; Nadah, J. Lowring sulfates from SO42-Rich geomaterials: A few tests regarding the hydraulic binders pathway. Int. J. Environ. Sci. Technol. 2021, 18, 2661-2674. [CrossRef] 
50. Espitalié, J.; Laporte, J.L.; Madec, M.; Marquis, F.; Leplat, P.; Paulet, J.; Boutefeu, A. Méthode rapide de caractérisation des roches mères, de leur potentiel pétrolier et de leur degré d'évolution. Rev. L'inst. Fr. Pét. 1977, 32, 23-42. [CrossRef]

51. Mahamat Ahmat, A.; Boussafir, M.; Le Milbeau, C.; Guégan, R.; Valdès, J.; Guiñez, M.; Le Forestier, L. Organic matter-clay interaction along a seawater column of the eastern Pacific upwelling system (Antofagasta bay, Chile): Implications for source rock organic matter preservation. Mar. Chem. 2016, 179, 23-33. [CrossRef]

52. Mahamat Ahmat, A.; Boussafir, M.; Le Milbeau, C.; Guégan, R.; De Oliveira, T.; Le Forestier, L. Organic matter and Clay interaction in a meromictic lake: Implication for source rock OM preservation. Org. Geochem. 2017, 109, 45-57. [CrossRef]

53. Özcan, A.S.; Erdem, B.; Özcan, A. Adsorption of acid blue 193 from aqueous solutions onto BTMA-bentonite. Colloids Surf. A Physicochem. Eng. Asp. 2005, 266, 73-81. [CrossRef]

54. Liu, R.; Zhang, B.; Mei, D.; Zhang, H.; Liu, J. Adsorption of methyl violet from aqueous solution by halloysite nanotubes. Desalination 2011, 268, 111-116. [CrossRef]

55. Sansalone, J.; Ying, G. Partitioning and granulometric distribution of metal leachate from urban traffic dry deposition particulate matter subject to acidic rainfall and runoff retention. Water Res. 2008, 42, 4146-4162. [CrossRef] [PubMed]

56. Mandzhieva, S.; Minkina, T.; Pinskiy, D.; Bauer, T.; Sushkova, S. The role of soil's particle-size fractions in the adsorption of heavy metals. Eurasian J. Soil Sci. 2014, 3, 197-205. [CrossRef]

57. Hills, A.W.D. The mechanism of thermal decomposition of calcium carbonate. Chem. Eng. Sci. 1968, 23, 297-320. [CrossRef]

58. L'vov, B.V. Mechanism of thermal decomposition of alkaline-earth carbonates. Thermochim. Acta 1997, 303, 161-170. [CrossRef]

59. Mohamed, M.; Yasup, S.; Maitra, S. Decomposition study of calcium carbonate in cockle shell. J. Eng. Sci. Technol. 2012, 7, 1-10.

60. Shuman, L.M. The effect of soil properties on zinc adsorption by soils. Soils Sci. Soc. Am. 1975, 39, 454-458. [CrossRef]

61. Young, L.B.; Harvey, H.H. The relative importance of manganese and iron oxides and organic matter in the sorption of trace metals by surficial lake sediments. Geochim. Cosmochim. Acta 1992, 56, 1175-1186. [CrossRef]

62. Lin, J.G.; Chen, S.Y. The relationship between adsorption of heavy metals and organic matter in river sediments. Environ. Int. 1998, 24, 345-352. [CrossRef]

63. Pérez-Novo, C.; Pateiro-Moure, M.; Osorio, F.; Novoa-Munoz, J.C.; Lopez-Periago, E.; Arias-Estévez, M. Influence of organic matter removal on competitive and noncompetitive adsorption of copper and zinc in acid soils. J. Colloid Interface Sci. 2008, 322, 33-40. [CrossRef]

64. Mizutani, K.; Fisher-Power, L.M.; Shi, Z.; Cheng, T. Cu and Zn adsorption to a terrestrial sediment: Influence of solid-tosolution ratio. Chemosphere 2017, 175, 341-349. [CrossRef]

65. Ören, A.K.; Kaya, A. Factors affecting adsorption characteristics of $\mathrm{Zn}^{2+}$ on two natural zeolites. J. Hazard. Mater. 2006, B131, 59-65. [CrossRef] [PubMed]

66. Sen, T.K.; Gomez, D. Adsorption of zinc $\left(\mathrm{Zn}^{2+}\right)$ from aqueous solution on natural bentonite. Desalination 2011, $267,286-294$. [CrossRef]

67. Clare, K.E.; Sherwood, P.T. The effect of organic matter on the setting on soil-cement mixtures. J. Appl. Chem. 1954, 4, 625-630 [CrossRef]

68. Clare, K.E.; Sherwood, P.T. Further studies on the effect of organic matter on the setting of soil-cement mixtures. J. Appl. Chem. 1956, 6, 317-324. [CrossRef]

69. Tremblay, H.; Duchesne, J.; Locat, J.; Leroueil, S. Influence of the nature of organic compounds on fine soil stabilization with cement. Can. Geotech. J. 2002, 39, 535-546. [CrossRef]

70. Chen, H.; Wang, Q. The behavior of organic matter in the process of soft soil stabilization using cement. Bull. Eng. Geol. Environ. 2006, 65, 445-448. [CrossRef]

71. Ma, C.; Chen, B. Effect of organic matter on strength development of self-compacting earth-based construction stabilized with cement-based composites. Constr. Build. Mater. 2016, 123, 414-423. [CrossRef]

72. Pan, Y.; Rossabi, J.; Pan, C.; Xie, X. Stabilization/solidification characteristics of organic clay contaminated by lead when using cement. J. Hazard Mater. 2019, 362, 132-139. [CrossRef]

73. Arnarson, T.S.; Keil, R.G. Mechanisms of pore water organic matter adsorption to montmorillonite. Mar. Chem. 2000, 71, 309-320. [CrossRef]

74. Keil, R.G.; Mayer, L.M. Mineral matrices and organic matter. Treatise Geochem. 2014, 12, 337-359.

75. Mahamat Ahmat, A.; Thiebault, T.; Guégan, R. Phenolic acids interactions with clay minerals: A spotlight on the adsorption mechanisms of Gallic Acid onto montmorillonite. Appl. Clay Sci. 2019, 180, 105188. [CrossRef]

76. Brigatti, M.F.; Corradini, F.; Franchini, G.C.; Mazzoni, S.; Medici, L.; Poppi, L. Interaction between montmorillonite and pollutants from industrial waste-waters exchange of $\mathrm{Zn}^{2+}$ and $\mathrm{Pb}^{2+}$ from aqueous solutions. Appl. Clay Sci. 1995, 9, 383-395. [CrossRef]

77. Ide, Y.; Ochi, N.; Ogawa, M. Effective and Selective Adsorption of $\mathrm{Zn}^{2+}$ from Seawater on a Layered Silicate. Angew. Chem. 2011, 123, 680-682. [CrossRef] 